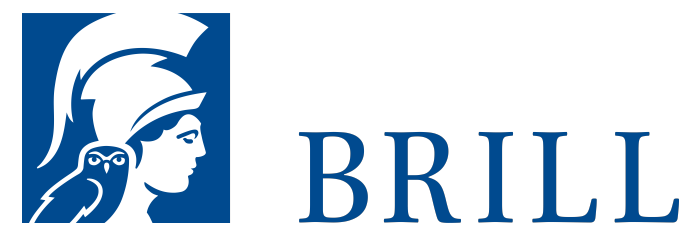

\title{
Interpretation and Meaning in Philosophy and Religion
}

\section{Editor: Dirk-Martin Grube}

\section{Interpretation and Meaning in Philosophy and Religion} synthesizes cutting-edge philosophical reflections on interpretation with their application to religion. For this, new theoretical insights on interpretation by Krausz, Lamarque, Leddy, Hagberg, and Gibson are examined. Topics cover multiplism (i.e. interpretative pluralism), the goal of interpretation and its starting point. These concepts are then studied in relation to the practice of interpreting religious texts. For example, Grube proposes that the action-relevance of religious interpretations limits the possibility of tolerating divergent interpretations, Karrer-Grube challenges Lamarque's insistence on a firm starting point, and Gokhale challenges Krausz by arguing that Vedantic practices of interpretation are non-multiplist.

\section{Readership}

All interested in the theory of interpretation and its application to a paradigmatic field of inquiry (viz. religion), i.e. philosophers of art and of religion, theologians, literary theorists, and historians.

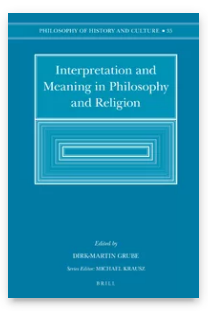

Pages: x, 189 pp.

Language:

English

Subjects:

Aesthetics \&

Cultural Theory, Philosophy, Philosophy of

Religion, Philosophy, Literature, Arts \& Science, Literature and Cultural Studies, Philosophy of Religion, Theology and World

Christianity

Publisher: Brill

Series:

Philosophy of

History and Culture, Volume: 35

E-Book (PDF)

Released online: 10 Jun 2016

ISBN: 978-9004-32524-1 List price USD \$149.00

Hardback 
Publication date:

23 Jun 2016

Dirk-Martin Grube, Ph.D. (1991) Temple

ISBN: $978-90-$

University/Philadelphia, Habilitation from Kiel University,

04-25499-2

Germany (1999). Chair of "Religious Diversity and the

List price

Epistemology of Theology/Religion" at VU University,

Amsterdam. He has published several monographs and more

than fifty articles on philosophy (of religion) and theology.

For more information see brill.com

Order information: Order online at brill.com +44330 3330049 | customerservices@brill.com Submission information: brill.com/authors

Titles published by Brill | Fink, Brill | mentis or Brill | Schöningh: +49(o)71 5413279216 | brill@brocom.de 